Article

\title{
Fluorescein Diacetate Hydrolysis Using the Whole Biofilm as a Sensitive Tool to Evaluate the Physiological State of Immobilized Bacterial Cells
}

\author{
Anna Dzionek ${ }^{1}$, Jolanta Dzik ${ }^{2}$, Danuta Wojcieszyńska ${ }^{1, *}$ and Urszula Guzik ${ }^{1}$ (D) \\ 1 Department of Biochemistry, Faculty of Biology and Environmental Protection, University of Silesia in \\ Katowice, Jagiellońska 28, 40-032 Katowice, Poland; adzionek@us.edu.pl (A.D.); \\ urszula.guzik@us.edu.pl (U.G.) \\ 2 Institute of Technology and Mechatronics, University of Silesia in Katowice, Żytnia 12, \\ 41-200 Sosnowiec, Poland; jolanta.dzik@us.edu.pl \\ * Correspondence: danuta.wojcieszynska@us.edu.pl; Tel.: +32-2009-567
}

Received: 16 August 2018; Accepted: 30 September 2018; Published: 2 October 2018

\begin{abstract}
Due to the increasing interest and the use of immobilized biocatalysts in bioremediation studies, there is a need for the development of an assay for quick and reliable measurements of their overall enzymatic activity. Fluorescein diacetate (FDA) hydrolysis is a widely used assay for measuring total enzymatic activity (TEA) in various environmental samples or in monoculture researches. However, standard FDA assays for TEA measurements in immobilized samples include performing an assay on cells detached from the carrier. This causes an error, because it is not possible to release all cells from the carrier without affecting their metabolic activity. In this study, we developed and optimized a procedure for TEA quantification in the whole biofilm formed on the carrier without disturbing it. The optimized method involves pre-incubation of immobilized carrier in phosphate buffer ( $\mathrm{pH}$ 7.6) on the orbital shaker for $15 \mathrm{~min}$, slow injection of FDA directly into the middle of the immobilized carrier, and incubation on the orbital shaker $\left(130 \mathrm{rpm}, 30^{\circ} \mathrm{C}\right)$ for $1 \mathrm{~h}$. Biofilm dry mass was obtained by comparing the dried weight of the immobilized carrier with that of the unimmobilized carrier. The improved protocol provides a simple, quick, and more reliable quantification of TEA during the development of immobilized biocatalysts compared to the original method.
\end{abstract}

Keywords: immobilization; fluorescein diacetate; polyurethane foam; biofilm; total enzymatic activity

\section{Introduction}

Increasing technological and civilization progress resulted in the level of anthropogenic pollution (e.g. pesticides, heavy metals, pharmaceuticals, dyes) in the natural environment increasing significantly in recent years. However, scientific progress made it possible to cheaply and effectively reduce the amount of these pollutants in the environment through bioremediation. This process is based on microorganisms equipped with systems of enzymes that allow them to obtain carbon and energy from xenobiotics [1-3].

An important attribute of stable bioremediation systems is their well-shaped microflora. For that reason, introduction of new microorganisms into the bioremediation systems very often ends, however, with their quick removal by the microflora present in the system. One of the common methods used to increase the chance of survival upon introducing microorganisms into the new system is their immobilization. In addition, immobilized biocatalysts bring certain advantages into bioremediation studies, such as reducing costs, ensuring a stable microenvironment for cells and their enzymes, and increasing the efficiency and resistance of biocatalysts to adverse environmental conditions and 
high pollutant concentration. Immobilized biocatalysts were extensively examined in the treatment of wastewaters contaminated with various pollutants, and their potential is promising [2,4-7].

Among various immobilization techniques, particular attention in bioremediation studies is paid to the ability of some bacterial strains to form biofilms on various materials. This technique is simple, fast, cheap, and non-toxic for cells and the environment. One of the most important advantages of this method, considering bioremediation systems, is also the spread of the introduced cells within the system, caused by the detachment of external parts of the biofilm in one of its growth phases. The necessary condition, in this technique, to receive a stable and efficient immobilized biocatalyst, is the development of a biofilm strongly attached to the surface of the carrier $[4,8-10]$. To obtain this kind of biofilm, it is necessary to optimize conditions of the immobilization process for each strain and the carrier $[4,11]$.

Currently, the most commonly method used to determine the efficiency of immobilization is the plate method which relies on plating and subsequent counting of colony-forming units (CFUs) released from the carriers [12] or determination of dry weight of the immobilized biomass [13]. However, none of the above methods determine the physiological state of immobilized cells, which is significantly affected by the quality of the formed biofilm. An indirect method allowing determination of immobilization efficiency is to conduct pollution degradation tests for which an immobilized biocatalyst was developed [14]. However, with multifactor optimization, determining the immobilization efficiency using this method is problematic, especially in the case of hardly biodegradable pollutants that are decomposed over a long period of time. In such cases, enzymatic determination of the metabolic activity of microbial cells may be the solution.

Fluorescein diacetate $\left(3^{\prime}, 6^{\prime}\right.$-diacetyl-fluorescein; FDA) is a prefluorophore, which can be hydrolyzed by a wide spectrum of non-specific extracellular enzymes and membrane-bound enzymes like proteases, lipases, and esterases. Fluorescein, which is a product of hydrolysis, has a yellow-green color and is characterized by strong light absorption at $490 \mathrm{~nm}$. For this reason, the concentration of fluorescein after enzymatic reactions can be easily measured spectrophotometrically. Moreover, measurements of enzymatic activity using FDA hydrolysis correlate with other parameters, such as biomass, ATP content, oxygen consumption, or optical density, and therefore, are often expressed as the total enzymatic activity (TEA) [15-17].

Despite its simplicity, determination of enzymatic activity of immobilized bacterial cells with FDA was presented so far in only one study [18]. The method proposed by Liang et al. [18] assumes the determination of FDA-hydrolyzing enzyme activity of cells that are detached from the carrier. A measurement of enzymatic activity performed in this way carries an error for two very important reasons. Firstly, it is impossible to detach the entire biofilm from the carrier in a non-toxic way because of the biofilm binding strength [19]. On the other hand, bacterial cells at different depths of the biofilm are characterized by different enzymatic activities [11,20]. Therefore, depending on the biofilm binding strength, its various layers with different enzymatic activities can be released and assumed as a total activity. In this study, we made an attempt to apply an appropriate modification to this method to eliminate the mentioned errors. The most important modification was to skip the step of cell removal from the biofilm and to conduct the FDA assay on the entire biofilm with the carrier. To achieve a reliable and reproductive assay, tests were started by determining the ability of carrier to adsorb the product of FDA hydrolysis. We also examined the influence of shaking, and determined which of the substrate application methods resulted in the highest FDA hydrolysis efficiency and the lowest coefficient of variation. Due to the fact that the repeatability and sensitivity of methods based on enzymatic activity depend on the operational conditions [21,22], the optimization of conditions such as $\mathrm{pH}$ and incubation time was performed. As a result, a sensitive and reproducible method was developed to determine the total enzymatic activity (TEA) of the entire biofilm formed on the carrier without disturbing it. Using this method, it is possible to determine the efficiency of immobilization during the optimization of its conditions quickly and precisely. 


\section{Results and Discussion}

\subsection{Fluorescein Adsorption by Polyurethane Foam (PUR)}

After the decision to carry out the enzymatic assay on the biofilm along with the carrier, particular attention should be paid to the possible interaction of the reaction product with the carrier. Fluorescein, without ionic functional groups (e.g., $\mathrm{COO}^{-}$), is characterized by very limited solubility in water. As the ionization increases, the interaction of the dye with oppositely charged functional groups of the carrier will also increase due to ion exchange. For this reason, the sorption of fluorescent dyes depends on both the $\mathrm{pH}$ and the functional groups of the carrier. Due to the presence of two negatively charged groups, and the absence of positive charges, fluorescein is much better adsorbed by positively charged surfaces than by negative ones [23-25].

In this study, the immobilization of the naproxen- and ibuprofen-degrading bacterium Bacillus thuringiensis B1 (2015b) [26] was conducted on PUR as a carrier. This is one of the most commonly used materials for microorganism immobilization, and it is characterized by good mechanical strength, non-toxicity, large surface area, and low price $[8,27]$. It was also shown that polyurethane foam, due to the presence of neutral carbamate groups, is a good sorbent of hydrophobic compounds $[8,28]$. Therefore, since fluorescein exhibits hydrophobic characteristics [24], its adsorption by polyurethane foam was investigated.

Sterile PUR cubes were incubated for $1 \mathrm{~h}$ with fluorescein formed during the hydrolysis of fluorescein diacetate to test the adsorption capacity of PUR. Conducted tests showed that, in the analyzed range of fluorescein concentrations $(0.5-5 \mu \mathrm{g} / \mathrm{mL})$, its adsorption by PUR did not exceed $9 \%$ of the dye, but the adsorption value depended on the initial concentration of fluorescein (Figure 1). The average value of adsorbed fluorescein in concentrations below $2.5 \mu \mathrm{g} / \mathrm{mL}$ was equal to $3.8 \pm 1.6 \%$, which was a statistically insignificant result ( $t$-test; $p \geq 0.05$ ). However, when the initial fluorescein concentration was higher than $2.5 \mu \mathrm{g} / \mathrm{mL}, 7.7 \pm 1.12 \%$ of dye adsorption was observed. Due to the fact that this result was a statistically significant difference ( $t$-test, $p \leq 0.05$ ), in this study, when the obtained concentration was in the range of $2.5-5 \mu \mathrm{g} / \mathrm{mL}$, the adsorption of fluorescein by PUR was included in the final concentration.

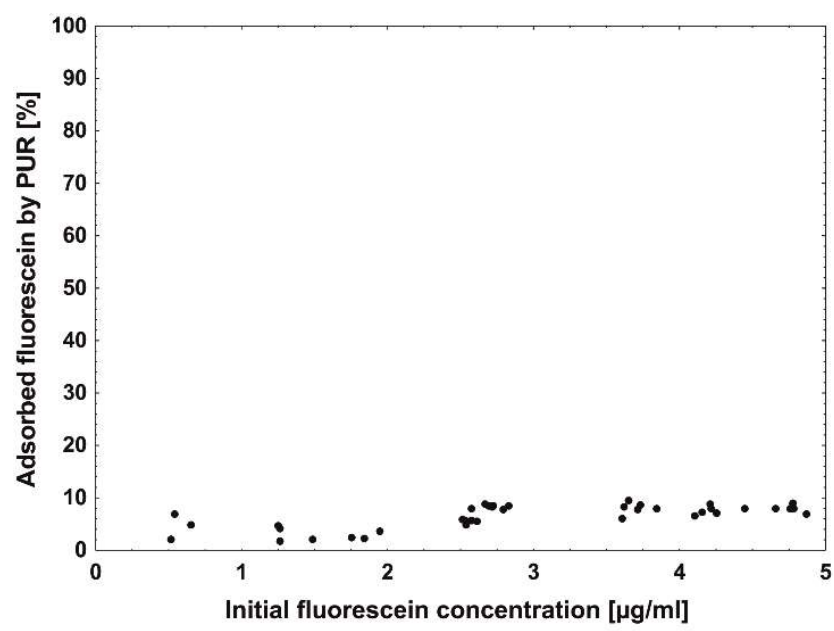

Figure 1. Fluorescein adsorption by sterile polyurethane foam (PUR) cubes depending on the initial concentration of the dye after $1 \mathrm{~h}$ of incubation.

Adsorption of fluorescein by materials used as carriers for immobilization is not yet extensively described. A good sorbent material, zeolite, was shown to adsorb $17 \%$ of the dye during overnight incubation [23]. However, the material which did not adsorb fluorescein, due to the negative charge of its surface, was silica gel [24]. 
The adsorption capacity of the carrier can be one of the most important factors which significantly affects the reliability of the FDA assay. For this reason, the adsorption test should be performed for each carrier at the beginning of the optimization of immobilization.

\subsection{Fluorescein Diacetate Application and Impact of Shaking}

Depending on bacterial strain, the physiological condition of the cells, and the environmental conditions, biofilms can be flat or consist of numerous water channels and extensive structures. They may contain a small number of cells and a rich matrix, or be very densely packed with cells. The structure of the biofilm and the condition of the cells at different depths differ significantly. However, the transport of water, metabolites, or nutrients in any type of biofilm is conducted in the same way. Mass transfer in the biofilm follows the principles of diffusion (in the biofilm matrix) and advection (in the water channels). Because mass transport in the biofilm is limited in its deeper layers, due to the slower diffusion through the matrix, a chemical gradient is created that affects the physiological state of cells at different heights of the biofilm $[4,11,20,29]$. For that reason, an examination of the physiological state of the biofilm should concern each of its layers. However, this causes technical complications that must be investigated to correctly perform the enzymatic assay and obtain reliable results.

In order to check whether the method of application of fluorescein diacetate would affect the reproducibility and efficiency of its hydrolysis, FDA was applied to the buffer solution or injected directly into the immobilized PUR cube and incubated for $1 \mathrm{~h}$. Depending on the site of FDA application, a different hydrolysis efficiency and coefficient of variation was observed (Table 1). The most reproducible and efficient result was obtained when the substrate was applied directly into the center of immobilized PUR cubes $(262 \pm 18 \mu \mathrm{g} / \mathrm{g}$ dry mass per $\mathrm{h})$. Addition of FDA to the phosphate buffer caused a large discrepancy in the obtained results (210 $\pm 48 \mu \mathrm{g} / \mathrm{g}$ dry mass per $\mathrm{h})$.

Table 1. Reproducibility of the method for determining fluorescein diacetate (FDA) hydrolytic activity depending on the method of FDA application. TEA — total enzymatic activity; SD—standard deviation; $\mathrm{CV}-$ coefficient of variation.

\begin{tabular}{ccccccc}
\hline $\begin{array}{c}\text { Location of } \\
\text { Application }\end{array}$ & $\begin{array}{c}\text { Biofilm Dry } \\
\text { Mass }(\mathrm{g})\end{array}$ & $\begin{array}{c}\text { Fluorescein } \\
\text { Concentration }(\mu \mathrm{g} / \mathrm{mL})\end{array}$ & $\begin{array}{c}\text { TEA } \\
(\boldsymbol{\mu} \mathrm{g} / \mathrm{g} \text { dry mass per } \mathbf{h})\end{array}$ & Mean & SD & CV (\%) \\
\hline Solution & $0.0082-0.0089$ & $1.35-2.30$ & $157-267$ & 210 & 48 & 23 \\
Carrier & $0.0084-0.0086$ & $2.02-2.40$ & $238-283$ & 262 & 18 & 7 \\
\hline
\end{tabular}

The immobilization of bacterial cells on polyurethane foam often results in the formation of a very abundant biofilm, both on its surface and inside the pores. As a result, a high cell density can be obtained in a small volume of the carrier, but also with limited mass transfer to the internal parts of the carrier $[20,30]$. For that reason, the application of FDA to the buffer solution could cause the adsorption of the FDA to only occur due to a biofilm located on the outer parts of the PUR. Therefore, different amounts of substrate could penetrate into the PUR interior, causing divergences. Nevertheless, it should also be taken into account that the release of fluorescein from the biofilm, especially from the internal parts of the carrier, may be slower due to the limited mass transfer and electrostatic repulsion with amino acids present in the biofilm matrix [31]. In order to achieve results with the smallest error, the final procedure assumes injecting the FDA directly into immobilized carriers placed in a phosphate buffer.

To evaluate the impact of agitation on the efficiency and reproducibility of FDA assay with immobilized B1 (2015b) cells on PUR, hydrolytic activity was measured after $1 \mathrm{~h}$ in static conditions, and upon subjection to a rotation rate of $130 \mathrm{rpm}$ (Table 2). Under static conditions, a higher concentration of fluorescein $(275 \mu \mathrm{g} / \mathrm{g}$ dry mass per $\mathrm{h}$ ) was observed in comparison to assays conducted with shaking ( $249 \mu \mathrm{g} / \mathrm{g}$ dry mass per $\mathrm{h})$. However, this result was the least reproducible as confirmed 
by the obtained coefficient of variation (46\%). Results obtained during assays shaken at $130 \mathrm{rpm}$ proved to be the most reproducible with the smallest coefficient of variation $(8 \%)$.

Table 2. Impact of shaking on the reproducibility of FDA assay.

\begin{tabular}{ccccccc}
\hline Agitation & $\begin{array}{c}\text { Dry Biofilm } \\
\text { Mass }(g)\end{array}$ & $\begin{array}{c}\text { Fluorescein } \\
\text { Concentration }(\mu \mathrm{g} / \mathrm{mL})\end{array}$ & $\begin{array}{c}\text { TEA } \\
(\mu \mathrm{g} / \mathrm{g} \text { dry mass per h) }\end{array}$ & Mean & SD & CV (\%) \\
\hline With & $0.0079-0.0086$ & $1.36-3.89$ & $164-469$ & 275 & 126 & 46 \\
Without & $0.0081-0.0089$ & $1.92-2.32$ & $226-273$ & 249 & 21 & 8 \\
\hline
\end{tabular}

In enzymatic assays, proper mixing is necessary to ensure sufficient substrate contact with enzyme active sites. However, excessive shaking, due to the shear forces, can deactivate the enzymes and reduce the efficiency of enzymatic reactions [32]. On the other hand, in static incubation, FDA will be rapidly hydrolyzed near the biofilm, while the rest of the FDA may not be transferred to the biofilm surface and matrix [17]. However, it was shown that shaking at below $200 \mathrm{rpm}$ does not damage the enzymes and provides the best efficiency of enzymatic reactions in soils [17,33]. For that reason, in the final method, samples were incubated with shaking at $130 \mathrm{rpm}$.

\section{3. pH Optimization}

One of the crucial factors influencing enzyme activity is the $\mathrm{pH}$ of the assay mixture. Therefore, each enzyme is characterized by a specific $\mathrm{pH}$ value at which it works most efficiently. At the optimal $\mathrm{pH}$, the active site of the enzyme is properly spatially shaped. This behavior is related to the proper protonation of amino acids included in the active site. However, due to the fact that FDA hydrolysis is carried out by many different enzymes, determining the optimum for the reaction involves determining the optimum of the enzyme group. It should also be noted that one of the FDA hydrolysis products is acetic acid; therefore, it is necessary to perform the assay in a buffer with an appropriate buffering capacity $[17,34]$. The temperature of the assay mixture also affects it $\mathrm{pH}$ value. Thus, to best assess the physiological state of the analyzed bacterial cells, the assay was carried out at the optimal temperature for their growth $\left(30^{\circ} \mathrm{C}\right)$.

In order to select the optimal $\mathrm{pH}$ of phosphate buffer, the hydrolysis of fluorescein diacetate in $\mathrm{pH}$-buffering solutions ranging from 6.8 to 7.6 was examined.

Conducted assays showed significant differences in FDA hydrolysis at different $\mathrm{pH}$ levels (Figure 2). Incubation of the immobilized B1 (2015b) strain with FDA in the buffer with the lowest $\mathrm{pH}$ (6.8) resulted in the smallest amount of released fluorescein in $1.5 \mathrm{~h}(54 \pm 6 \mu \mathrm{g} / \mathrm{g}$ dry mass per $\mathrm{h})$. As the $\mathrm{pH}$ of the buffer increased, hydrolytic activity also increased. Maximum FDA hydrolysis was observed at pH 7.4-7.6 (138 $\pm 7 \mu \mathrm{g} / \mathrm{g}$ dry mass per $\mathrm{h}$ to $128 \pm 5 \mu \mathrm{g} / \mathrm{g}$ dry mass per $\mathrm{h}$ ). According to Guilbault and Kramer [35], FDA-hydrolyzing enzymes exhibit the highest activity at a $\mathrm{pH}$ from 7 to 8 . However, most researchers use $\mathrm{pH}$ 7.6, which is very beneficial [22], mainly because of the fact that abiotic FDA hydrolysis is statistically significant at higher $\mathrm{pH}$ values. For this reason, $\mathrm{pH}$ above 7.6 was not examined during evaluation. 


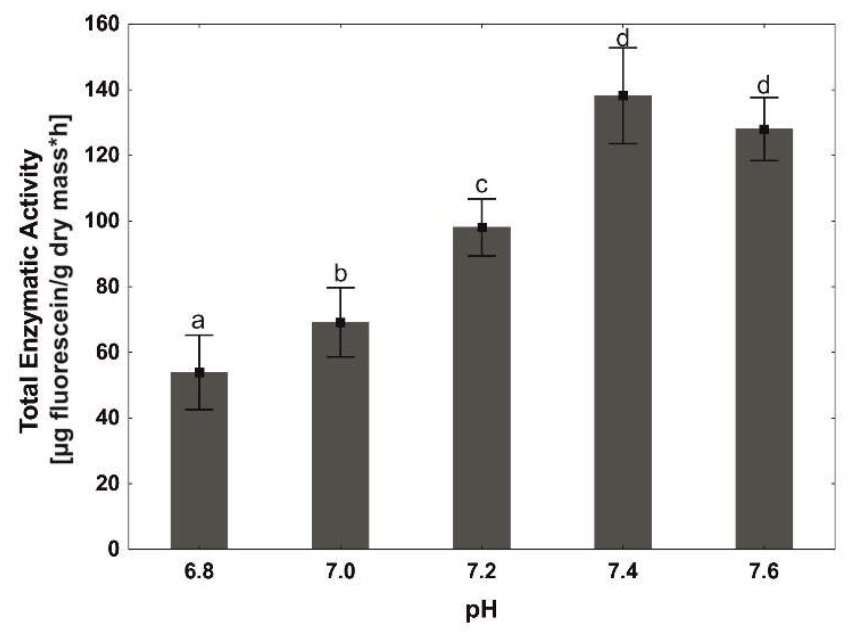

Figure 2. Effect of $\mathrm{pH}$ on the enzymatic hydrolysis of fluorescein diacetate (FDA) by Bacillus thuringiensis B1 (2015b) cells immobilized onto PUR. Error bars were obtained based on the standard deviation. Statistically significant differences are marked with letters (post hoc, $p \leq 0.05$ ).

Depending on the type of the carrier and its ionization, $\mathrm{pH}$ of the environment may influence abiotic degradation of FDA [17]. In this study, abiotic and spontaneous FDA hydrolysis in the presence of PUR in the analyzed $\mathrm{pH}$ range was not statistically significant (data not shown).

The lack of background in quantification of microbial enzymatic activity is undoubtedly an advantage. However, not every carrier will affect the abiotic FDA degradation; therefore, the above test should be performed in phosphate buffer ( $\mathrm{pH}$ 7.6) before the FDA assay with immobilized cells.

\subsection{Incubation Time}

The biofilm matrix is a complex mixture of many compounds such as polymers, proteins, polysaccharides, and nucleic acids. Other important components of the biofilm matrix are also cellular elements, including enzymes. They may come from autolysed cells or may be secreted by viable cells to facilitate degradation of macromolecular substances adsorbed by extracellular polymeric substances (EPS) [11,20]. Frølund et al. [36] also demonstrated the presence of enzymes responsible for the hydrolysis of FDA in the biofilm matrix. They observed much greater enzymatic activity per cell in activated sludge flocs than in sludge cultures. Jørgensen et al. [37] also noted that they may be responsible for $20-30 \%$ of FDA hydrolysis reactions from samples. However, due to the anionic nature of the biofilm, accumulation of negatively charged fluorescein in the biofilm matrix after $1.5 \mathrm{~h}$ of incubation was not statistically significant (data not shown).

In this study, we investigated the temporal variation of fluorescein release from B1 (2015b) cells immobilized onto PUR during $1.5 \mathrm{~h}$ of incubation. A linear relationship was observed throughout all analyzed times of incubation with the maximum amount of released fluorescein after $1.5 \mathrm{~h}$ of incubation $(128 \pm 5 \mu \mathrm{g} / \mathrm{g}$ dry mass per h, Figure 3). This result show that FDA hydrolysis was not limited by substrate concentration over the analyzed period of time. Due to the fact that the assay was conducted at a favorable temperature for bacterial cell proliferation $\left(30^{\circ} \mathrm{C}\right)$ [38], it was suggested that a long-term incubation could lead to a result that would not reflect the enzymatic activity of the original sample [17,22,39]. Adam and Duncan [39] also pointed out that it is more important to estimate the hydrolytic potential of the samples than to obtain the highest concentration of fluorescein; therefore, they recommend that incubation last not longer than one hour. On the other hand, Green et al. [22] recommended that incubation last longer than $2 \mathrm{~h}$ for soil samples, thereby allowing better differentiation of the results. 


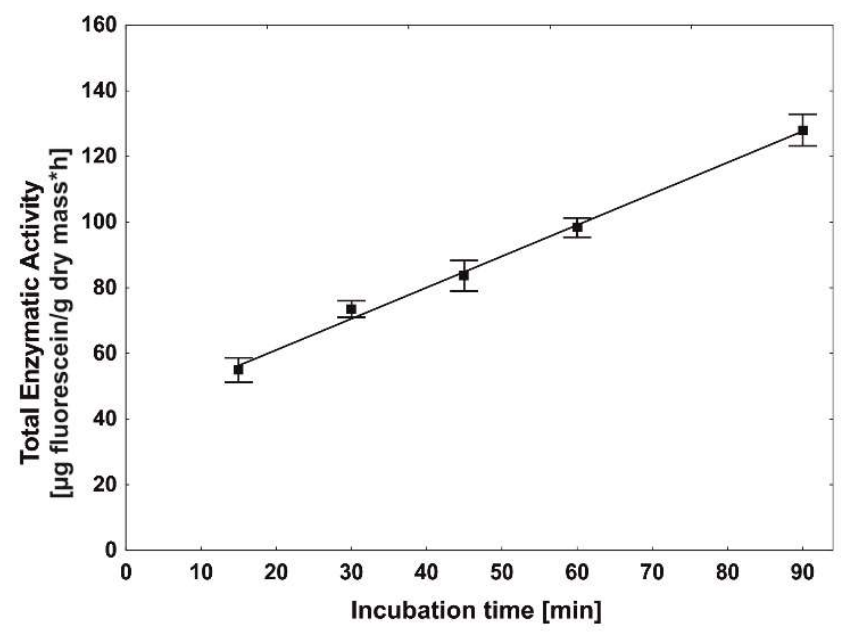

Figure 3. Fluorescein release over time during FDA hydrolysis by immobilized B1 (2015b) cells onto PUR. Error bars were obtained based on the standard deviation.

In the analyzed period of time, errors associated with the growth of microorganisms were eliminated. However, to allow a longer differentiation of samples, an incubation time of $1 \mathrm{~h}$ was chosen for the final procedure.

\subsection{Sensitivity Assay—Carbon Starvation}

The incubation time during immobilization is an extremely important parameter which determines the formation of a stable and strong biofilm, which, after reaching maturity, will be fully resistant to adverse environmental conditions and will be able to degrade higher concentrations of impurities. However, to produce biofilms, bacterial cells must be metabolically active. One of the basic factors affecting metabolic activity is the availability of easily assimilable carbon sources. During a shortage of carbon sources, bacterial cells will reduce their size, and very often, their shape as well (they become more round). If, however, nutrition level drops to a minimum, the response to these conditions involves limiting endogenous metabolism to such a level that they will not be able to reproduce, but will remain active [40-42]. Under these conditions, the vegetative bacterial cells can survive, depending on the strain, from a few to even 100 days (e.g., Arthrobacter crystallopoietes) [43].

In order to determine sensitivity of the optimized method, it was observed how the total enzymatic activity (TEA) of bacterial cells in the developing biofilm decreased to the point of minimal endogenous metabolism under starvation during the immobilization process. Seventy-two hours of incubation without a carbon source in the medium resulted in a gradual decrease in TEA (Table 3). After $24 \mathrm{~h}$ of incubation, when immobilized B1 (2015b) cells were using accumulated sources of energy, the highest enzymatic activity ( $360 \pm 24 \mu \mathrm{g} / \mathrm{g}$ dry mass per $\mathrm{h}$ ) was observed. Along with the progressing starvation, after $72 \mathrm{~h}$, a nearly twofold reduction in mean TEA was observed (170 $\pm 7 \mu \mathrm{g} / \mathrm{g}$ dry mass per $\mathrm{h}$ ), which indicates the exhaustion of energy reserves and restriction of metabolic activity. The obtained results agree with those obtained by Gengenbacher et al. [44] and Voelker et al. [45], in which a significant decrease in the amount of ATP was demonstrated in nutrient-starved Bacillus subtilis and Mycobacterium tuberculosis, which indicates a reduction of metabolic activity. It should be also noted that the obtained fluorescein concentration after the analyzed period of time does not differ despite increasing biofilm mass (Table 3). This result can be caused by continuous EPS production by bacterial cells without progressing colonization of the carrier. However, monitoring of the changes in the optical density $\left(\mathrm{OD}_{600}\right)$ of the medium during immobilization reveal that, with progressing incubation, more cells migrated from the medium. After 24,48 , and $72 \mathrm{~h}$, reductions in the initial $\mathrm{OD}_{600}$ value were observed to be $39.5 \pm 0.9,48.8 \pm 3.5$, and $54.8 \pm 9.1 \%$, respectively. It was observed also that, despite the increasing amount of EPS during incubation, it did not exceed $13-15 \%$ of the 
biofilm mass (Table 3). These results clearly indicate that the drop in TEA was caused by the decreasing activity of newly colonizing bacterial cells, instead of the increasing amount of EPS.

Table 3. Impact of carbon starvation on the TEA of the immobilized Bacillus thuringiensis B1 (2015b) strain during the immobilization process. EPS—extracellular polymeric substances.

\begin{tabular}{|c|c|c|c|c|c|c|c|}
\hline $\begin{array}{l}\text { Incubation } \\
\text { time (h) }\end{array}$ & $\begin{array}{l}\text { Biofilm dry } \\
\text { mass (g) }\end{array}$ & $\begin{array}{l}\text { Dry EPS } \\
\text { mass(g) }\end{array}$ & $\begin{array}{c}\text { Fluorescein } \\
\text { concentration }(\mu \mathrm{g} / \mathrm{ml})\end{array}$ & $\begin{array}{c}\text { TEA } \\
(\mu \mathrm{g} / \mathrm{g} \text { dry mass per } \mathrm{h})\end{array}$ & Mean & SD & CV (\%) \\
\hline 24 & $0.0034-0.0049$ & $0.0005-0.0007$ & $1.21-1.66$ & $326-383$ & 360 & 24 & 7 \\
\hline 72 & $0.0080-0.0091$ & $0.0010-0.0013$ & $1.43-1.50$ & $166-180$ & 170 & 7 & 4 \\
\hline
\end{tabular}

In comparison to the TEA values obtained from planktonic B1 (2015b) cells present in the medium, cells immobilized in the biofilm were characterized by better resistance to starvation. After $48 \mathrm{~h}$ of incubation, unimmobilized B1 (2015b) cells showed the lowest TEA value $(161 \pm 17 \mu \mathrm{g} / \mathrm{g}$ dry mass per $\mathrm{h}$ ), which was maintained until the end of the analyzed period of time. This result shows that the TEA in the range of 160-170 $\mu \mathrm{g} / \mathrm{g}$ dry mass per $\mathrm{h}$ indicated that the B1 cells $(2015 \mathrm{~b})$ were limited to endogenous metabolism.

It was noticed that starvation of Bacillus thuringiensis B1 (2015b) cells promoted their immobilization on polyurethane foam. To observe the progress of immobilization, SEM micrographs were prepared after 24,48 , and $72 \mathrm{~h}$ of incubation of polyurethane foam with Bacillus thuringiensis B1 (2015b) cells (Figure 4).

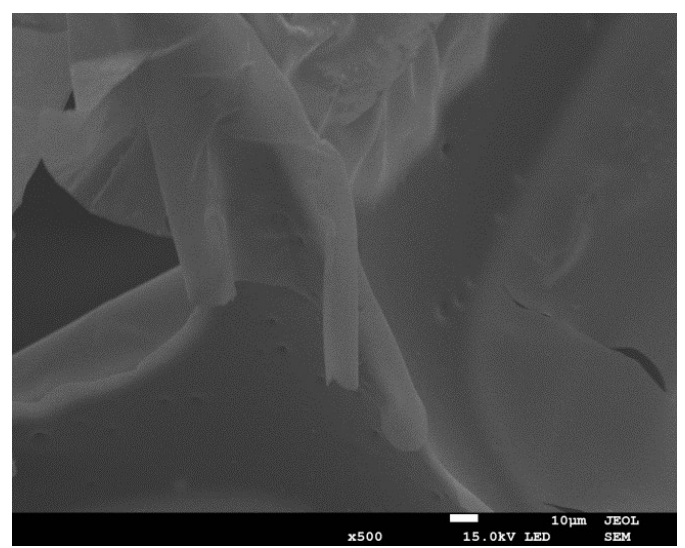

(a)

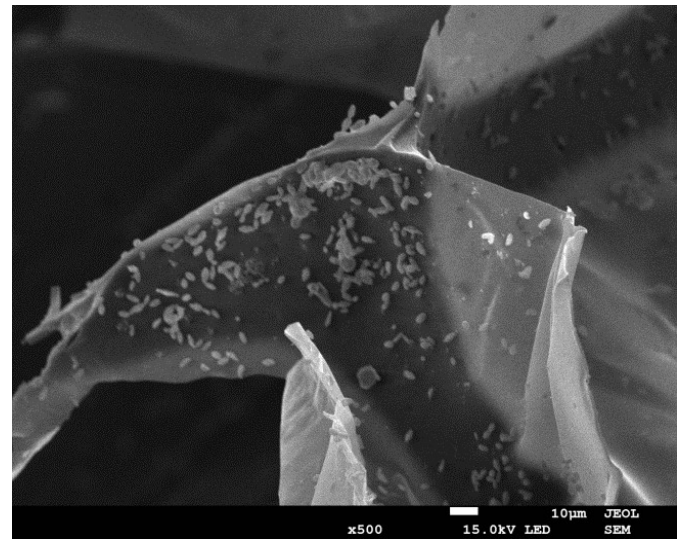

(c)

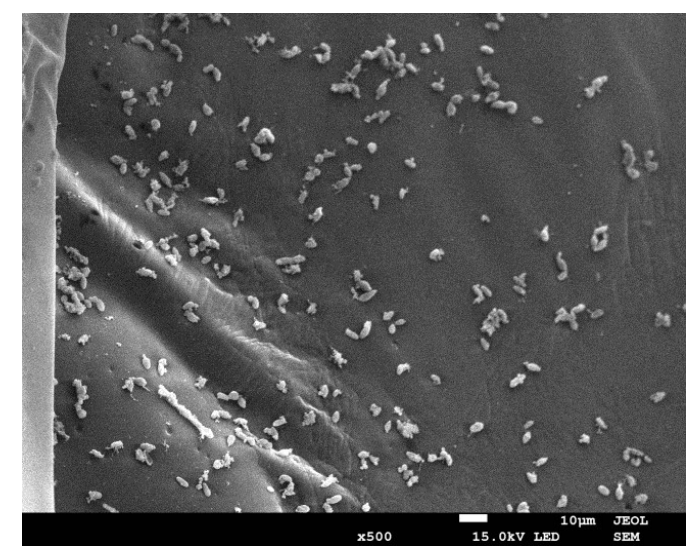

(b)

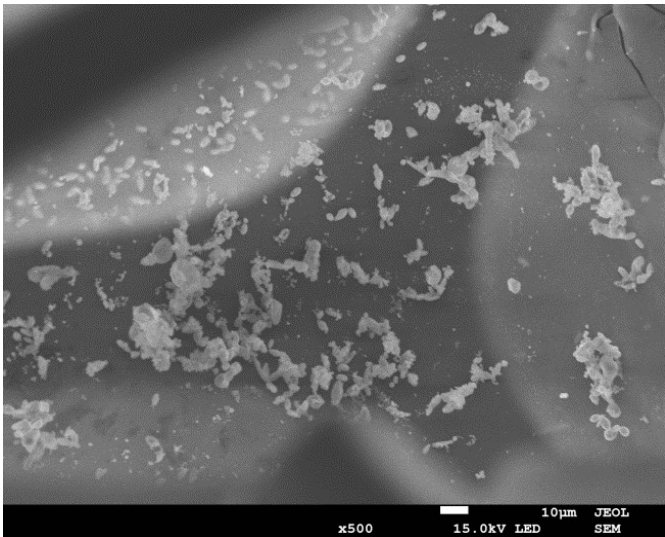

(d)

Figure 4. SEM micrographs of biofilm formation by the B1 (2015b) strain onto PUR cubes during starvation after $24 \mathrm{~h}(\mathbf{b}), 48 \mathrm{~h}(\mathbf{c})$, and $72 \mathrm{~h}(\mathrm{~d})$ of incubation. The surface of the unimmobilized control PUR cube is shown in (a). 
As can be seen in Figure $4 b$, the colonization of polyurethane foam by B1 (2015b) cells was already evident after $24 \mathrm{~h}$ of immobilization. Adsorption of bacterial cells onto the surface of polyurethane foam was observed, which indicates the start of the biofilm formation process. Over time, the bacterial cells began forming microcolonies and secreting extracellular polymeric substances (EPS; Figure 4c). After $72 \mathrm{~h}$, accumulated cells and extracellular matrices in the form of connected aggregates were observed on the PUR surface (Figure 4d). As is known, the limitation of nutrients such as carbon, nitrogen, or phosphorus in the medium is an inducer of sporulation in Bacillus subtilis and Bacillus cereus cells. The transcription factor $S p o 0 A$ is activated, which, apart from participating in the production of spores, also promotes the formation of biofilm by induction of EPS production. This is one of the defense mechanisms of this genus during the absence of nutrients [46,47]. Due to the fact that the Spo0A gene was found in the genome of Bacillus thuringiensis [48,49], the mechanism of biofilm induction during starvation in B. thuringiensis B1 (2015b) used in this study could be similar. As a result, the decrease in total enzymatic activity of immobilized B1 (2015b) cells was caused by spending energy reserves on EPS synthesis and biofilm formation.

During estimation of the immobilization efficiency, only by determining the dry mass of immobilized bacterial cells could $72 \mathrm{~h}$ of incubation be considered optimal. However, after examination of the enzymatic activity, it is shown that the bacterial cells were weakened. The biodegradation tests in this case could be significantly prolonged due to the time when the biofilm would be regenerating. If, however, contamination indicates toxic effects on the strain, it could even lead to their death. With the developed method, it is possible to examine the physiological state of the biofilm formed on the carrier, thereby optimizing the immobilization process, allowing one to obtain a biofilm with the highest enzymatic activity.

\subsection{Comparision of the Modified FDA Method with Oxygen Consumption}

Oxygen is the key substrate conditioning the metabolism of aerobic organisms. It is necessary for ATP synthesis, and therefore, for the growth, proliferation, and synthesis of various cellular elements. However, due to its poor solubility in water, cultures of aerobic microorganisms must be constantly mixed to ensure its transition from the gas phase. For this reason, oxygen availability in the medium can be a growth-limiting factor for cell cultures [50]. Because of the unique mass transfer properties of biofilms, they are able to adsorb oxygen even at low concentrations. As a result, biofilms ensure, in the top layers, a constant amount of oxygen depending on the cell's oxygen demand, which, in turn, results from the physiological state of bacterial cells [51]. Recent studies showed that differences in oxygen concentration in the horizontal direction at the same depth of aerobic biofilms are statistically insignificant; however, like the previously mentioned nutrients, they are significant in the vertical direction $[52,53]$.

The oxygen uptake rate (OUR), due to its good correlation with metabolic activity, provides valuable information on the physiological state of microbial cells. Due to its relatively simple calculation, OUR is often used to characterize activated sludge [54], production processes [55], and bioremediation [56,57].

To test whether the optimized method would present the same relationships as those used to assess the physiological state of microbial cells, the oxygen uptake rate (OUR) was measured during the starvation assay described above. Table 4 summarizes the obtained values of OUR and TEA after 24, 48, and $72 \mathrm{~h}$ of incubation of B1 (2015b) cells with PUR in a medium without carbon sources. The trend in oxygen uptake rate showed a very good correlation with the decrease in total enzymatic activity. After $72 \mathrm{~h}$, immobilized cells showed a nearly twofold reduction in OUR (70 $\pm 4 \mu \mathrm{g} / \mathrm{g}$ dry mass per $\mathrm{h}$ ) compared to values obtained after $24 \mathrm{~h}$ of incubation $(176 \pm 13 \mu \mathrm{g} / \mathrm{g}$ dry mass per $\mathrm{h})$. A similar decrease in OUR value in a trickling filter biofilm was also observed by Cox et al. [41] in the absence of toluene, which was the only carbon source in the experiment. 
Table 4. Comparison of TEA and oxygen uptake rate (OUR) during carbon starvation of immobilized B1 (2015b) cells during the immobilization process. Data are presented as means \pm standard deviation of three replicates.

\begin{tabular}{ccc}
\hline Incubation time $(\mathbf{h})$ & $\begin{array}{c}\text { TEA } \\
(\boldsymbol{\mu g} / \mathbf{g} \text { dry mass per } \mathbf{h})\end{array}$ & $\begin{array}{c}\text { OUR } \\
\left(\boldsymbol{\mu g ~ \mathbf { ~ O } _ { 2 }} / \mathbf{g} \text { dry mass } \text { per } \mathbf{h}\right)\end{array}$ \\
\hline 24 & $360 \pm 24$ & $176 \pm 13$ \\
48 & $287 \pm 28$ & $120 \pm 9$ \\
72 & $170 \pm 7$ & $70 \pm 4$ \\
\hline
\end{tabular}

A comparison of the proposed and optimized method in this study for evaluating the physiological state of immobilized cells in biofilms and the method based on the determination of oxygen uptake requires a consideration of the advantages and disadvantages of each technique. OUR is well-established method that allows an indirect estimation of metabolic activity. Its biggest advantage is the duration of the measurement, because results can be obtained after 10 minutes. On the other hand, this method requires experience, due to the fact that, depending on the method of flask sealing and oxygen removal from the gas phase, the result may be burdened with various errors caused by the transfer of oxygen from the air. The determination of the physiological state by direct analysis of the activity of non-specific enzymes responsible for organic matter degradation proposed herein does not require any technical steps that may disturb the final results.

To conclude, in this study, a modification of the FDA assay was optimized in a way which allows results which are reproducible and have a low coefficient of variation. The result also implies the diversity of activities resulting from the heterogeneity of the biofilm. However, due to the possible fluorescein adsorption by the carrier, it is necessary to carry out adsorption tests. With the proposed method, it is possible to monitor changes in the physiological state of the biofilm formed on the carrier through optimization of the immobilization process. By conducting the optimization in this way, the development of an immobilized biocatalyst was possible with the highest enzymatic activity, and thus, with the highest biodegradation capacity or resistance to harsh environmental conditions.

\section{Materials and Methods}

\subsection{Materials}

Polyurethane foam (PUR) used in this study is a commonly used material to protect packages during transport (Instapak ${ }^{\circledR}$, Charlotte, NY, USA). The carrier was trimmed into $1 \times 1 \times 1 \mathrm{~cm}$ cubes with a weight of $10 \pm 5 \mathrm{mg}$, and was washed two times with distilled water to remove impurities, before being autoclaved $\left(121^{\circ} \mathrm{C}, 1.2 \mathrm{~atm}, 20 \mathrm{~min}\right)$. All the chemicals were purchased from Sigma-Aldrich (St. Louis, MO, USA).

\subsection{Bacterial Strains and Growth Conditions}

Bacterial strain Bacillus thuringiensis B1 (2015b) isolated from the soil of the chemical factory "Organika-Azot" in Jaworzno (Poland) was used for immobilization [26]. Strain B1 (2015b) was grown in the nutrient broth (BBL) at $30{ }^{\circ} \mathrm{C}$ on a rotary shaker at $130 \mathrm{rpm}$ for $24 \mathrm{~h}$. After cultivation, cells were harvested by centrifugation ( $5000 \mathrm{rpm}, 15 \mathrm{~min}$ ), washed twice with a sterile mineral salt medium according to Greń et al. [58], and re-suspended in the same medium. A bacterial suspension at a final concentration corresponding to an optical density $\left(\mathrm{OD}_{600}\right)$ of 0.8 was used for immobilization.

\subsection{Immobilization Procedure}

Each Erlenmeyer flask $(250 \mathrm{~mL})$ containing sterile carrier material $(0.1 \mathrm{~g})$ was inoculated with the bacterial cell suspension (100 mL). The mineral salt medium [58] in which the immobilization process was conducted did not contain any carbon sources. The immobilization process was carried out on the orbital shaker (130 rpm) at $30^{\circ} \mathrm{C}$ for $72 \mathrm{~h}$. After incubation, the medium was removed 
and immobilized PURs were suspended in $\mathrm{NaCl}$ solution (0.9\%), centrifuged at $500 \mathrm{rpm}$ for $2 \mathrm{~min}$ to remove unbound microorganisms, rinsed with $0.9 \% \mathrm{NaCl}$, and used for further analysis.

\subsection{Standard Method of Non-Specific Esterase Activity with FDA Assay}

The physiological state of the bacterial cells was determined via measurements of non-specific esterase activity with fluorescein diacetate (FDA) as a substrate. The original method [18] includes detaching microorganisms from the carriers by shaking $(5 \mathrm{~g})$ in $100 \mathrm{~mL}$ of distilled water $(200 \mathrm{rpm}$, $30 \mathrm{~min}$ ). In the next step, $2 \mathrm{~mL}$ of the microorganism suspension was added to $8 \mathrm{~mL}$ of phosphate buffer (pH 7.0) and incubated for 15 min with shaking at $30^{\circ} \mathrm{C}$. After pre-incubation, $0.1 \mathrm{~mL}$ of FDA stock solution $(4.8 \mathrm{mM}$, dissolved in acetone) was added to each sample and incubated for $2 \mathrm{~h}$. Fluorescein concentration was measured spectrophotometrically (Genesys 20, Thermo Fisher Scientific, Inc., Rochester, NY, USA) at $490 \mathrm{~nm}$ and was calculated on the basis of a standard curve.

\subsection{Abiotic Controls for FDA Assay}

To examine fluorescein adsorption by PUR, sterile carrier cubes (one cube per assay) were placed in solutions with different concentrations $(0.5-5 \mu \mathrm{g} / \mathrm{mL})$ of sterile fluorescein suspended in phosphate buffer (pH 7.0) and incubated in the dark on the orbital shaker $\left(130 \mathrm{rpm}, 30^{\circ} \mathrm{C}\right)$. After $1 \mathrm{~h}$ of incubation, absorbance $(\lambda=490 \mathrm{~nm})$ was measured. Additionally, control samples were prepared in the case of FDA autohydrolysis and the natural coloration of the sample with and without sterile carriers.

\subsection{Optimization Procedure}

The main aim of the optimization procedure was to skip the step of detachment of microorganisms from the carrier in such a way to allow testing of the enzymatic activity of the entire biofilm formed on the carrier without disturbing it. For the best reproducibility, the impacts of substrate application method (FDA added to the liquid or into the carrier) and agitation (with or without) were examined. In order to maximize the activity of non-specific esterases, optimizations of the $\mathrm{pH}(6.8-7.6)$ and of the incubation time of immobilized strain B1 (2015b) (15-90 min) with FDA solution were also performed.

\subsection{Modified Method of Non-Specific Esterase Activity with FDA Assay}

The final methodology is defined as follows: an immobilized PUR cube was placed into $8 \mathrm{~mL}$ of phosphate buffer ( $\mathrm{pH}$ 7.6) and incubated for $15 \mathrm{~min}$ on the orbital shaker. In the next step, $0.1 \mathrm{~mL}$ of FDA solution in acetone $(4.8 \mathrm{mM})$ was slowly injected directly into the middle of the carrier and incubated on the orbital shaker $\left(130 \mathrm{rpm}, 30^{\circ} \mathrm{C}\right)$ for $1 \mathrm{~h}$. Fluorescein concentration was measured as described in Section 3.4.

\subsection{Sensitivity Assay-Carbon Starvation}

To determine the sensitivity of the method, the impact of carbon starvation on the metabolic response of bacterial cells and the immobilization process was monitored and expressed as total enzymatic activity (TEA). In this test, bacterial cells were immobilized onto PUR as described in Section 3.3 with the incubation time varied to 24,48 , or $72 \mathrm{~h}$. After incubation, the FDA hydrolysis potential of the immobilized bacterial cells was examined. The biofilm's dry mass was calculated by comparing the dried weight of the immobilized carrier (dried at $105{ }^{\circ} \mathrm{C}$ for $2 \mathrm{~h}$ and stored in a desiccator) with that of the unimmobilized carriers incubated and dried under the same conditions. TEA was expressed in $\mu \mathrm{g}$ of fluorescein obtained from $1 \mathrm{~g}$ of biofilm dry mass for $1 \mathrm{~h}$ [59]. TEA values for unimmobilized cells of B1 (2015b) were obtained in the same way as for immobilized cells, except that $2 \mathrm{~mL}$ of the culture was added to the phosphate buffer ( $\mathrm{pH} \mathrm{7.6)}$ and, after $1 \mathrm{~h}$ of incubation with FDA, bacterial cells were collected through filtration on $0.2-\mu \mathrm{m}$ Nuclepore filters $[15,17,59]$. Migration of the bacterial cells from the medium was determined using spectrophotometry $\left(\mathrm{OD}_{600}\right.$; Genesys 20 , Thermo Fisher Scientific, Inc., Rochester, NY, USA). EPS extraction from the immobilized PUR cubes 
was conducted according to the protocol proposed by Subramanian et al. [60] with some modifications. The PUR cube after 24,48 , or $72 \mathrm{~h}$ of incubation was transferred from the medium into $20 \mathrm{~mL}$ of distilled water, centrifuged ( $500 \mathrm{rpm}$ for $2 \mathrm{~min}$ ) to remove unbound microorganisms, and re-suspended in the same volume of Milli-Q water (Burlington, MA, USA). In the next step, the sample was ultrasonically treated three times for $15 \mathrm{~s}$ with a time interval of $10 \mathrm{~s}$, and centrifuged (without carrier, $14000 \mathrm{rpm}$ for $20 \mathrm{~min}$ at $4{ }^{\circ} \mathrm{C}$ ). The collected supernatant containing EPS was precipitated with 2.2 volumes of absolute chilled ethanol through incubation of the mixture at $20^{\circ} \mathrm{C}$ for $1 \mathrm{~h}$, and was separated by centrifugation at $6000 \mathrm{rpm}$ for $15 \mathrm{~min}$ at $4{ }^{\circ} \mathrm{C}$. The dry EPS mass was obtained by drying the pellet at room temperature and overnight storage in the desiccator.

\subsection{Scanning Electron Microscopy}

Scanning electron microscopy (SEM) was used to illustrate biofilm formation onto a carrier during starvation. For this purpose, immobilized carrier cubes were fixed in 3\% glutaraldehyde and 1\% osmium tetroxide, dehydrated with ethanol (30,50,70, 80,90, 95, and 100\%, each for $10 \mathrm{~min}$ ), dried by lyophilization, covered with gold, and observed with a high-resolution electron microscope JSM-7100F TTL LV (JEOL, Tokio, Japan).

\subsection{Oxygen Consumption}

Oxygen uptake rate (OUR) was determined using an Elmetron multiparameter equipped with a Clark electrode. One immobilized PUR cube was introduced into a flask containing $15 \mathrm{~mL}$ of oxygen-saturated phosphate buffer $\left(\mathrm{pH} 7.6,20^{\circ} \mathrm{C}\right)$. To minimize the measurement error, the vessels were placed on a magnetic stirrer and sealed. The decrease in oxygen concentration was registered every $30 \mathrm{sec}$ for $10 \mathrm{~min}$. Oxygen uptake rate was calculated from the slope of a linear regression line through the obtained results and expressed as OUR ( $\mu \mathrm{g}$ of consumed $\mathrm{O}_{2}$ by $1 \mathrm{~g}$ of biofilm dry mass during $1 \mathrm{~h})[54,61]$.

\subsection{Statistical Analysis}

All experiments were performed in at least three replicates. The values of the efficiency of immobilization and enzyme activities were analyzed by one-way ANOVA ( $p \leq 0.05$ was considered significant) using the STATISTICA 12 PL software package (StatSoft Inc., Kraków, Poland). A post hoc test was applied to assay the differences between the treatments. To express the repeatability and precision of conducted assays, the coefficient of variation $(\mathrm{CV})$ was calculated as the quotient of the standard deviation and the mean of the obtained TEA from each flask.

Author Contributions: Conceptualization, A.D. and U.G. Data curation, A.D. Formal analysis, D.W. Investigation, A.D. Methodology, A.D. Supervision, U.G. Visualization, J.D. Writing-original draft, A.D., D.W., and U.G. Writing-review and editing, A.D., D.W., and U.G.

Funding: This work was financed by the National Science Centre (Poland), granted on the basis of decision DEC-2017/25/N/NZ9/00422.

Acknowledgments: We are grateful to Justyna Michalska for help with the oxygen uptake rate assay and Małgorzata Adamczyk-Habrajska for help with the preparation of SEM micrographs.

Conflicts of Interest: The authors declare no conflicts of interest.

\section{References}

1. Wojcieszyńska, D.; Domaradzka, D.; Hupert-Kocurek, K.; Guzik, U. Enzymes Involved in Naproxen Degradation by Planococcus sp. S5. Pol. J. Microbiol. 2016, 65, 177-182. [CrossRef] [PubMed]

2. Dzionek, A.; Wojcieszyńska, D.; Guzik, U. Natural carriers in bioremediation: A review. Electron. J. Biotechnol. 2016, 19, 28-36. [CrossRef]

3. Bayat, Z.; Hassanshahian, M.; Cappello, S. Immobilization of microbes for bioremediation of crude oil polluted environments: A mini review. Open Microbiol. J. 2015, 9, 48-54. [PubMed] 
4. Dzionek, A.; Wojcieszyńska, D.; Hupert-Kocurek, K.; Adamczyk-Habrajska, M.; Guzik, U. Immobilization of Planococcus sp. S5 strain on the loofah sponge and its application in naproxen removal. Catalysts 2018, 8, 176. [CrossRef]

5. Partovinia, A.; Rasekh, B. Review of the immobilized microbial cell systems for bioremediation of petroleum hydrocarbons polluted environments. Crit. Rev. Environ. Sci. Technol. 2018, 48, 1-38. [CrossRef]

6. Sarioglu, O.F.; Celebioglu, A.; Tekinay, T.; Uyar, T. Evaluation of fiber diameter and morphology differences for electrospun fibers on bacterial immobilization and bioremediation performance. Int. Biodeterior. Biodegradation 2017, 120, 66-70. [CrossRef]

7. Mrozik, A.; Piotrowska-Seget, Z. Bioaugmentation as a strategy for cleaning up of soils contaminated with aromatic compounds. Microbiol. Res. 2010, 165, 363-375. [CrossRef] [PubMed]

8. Alessandrello, M.J.; Parellada, E.A.; Juárez Tomás, M.S.; Neske, A.; Vullo, D.L.; Ferrero, M.A. Polycyclic aromatic hydrocarbons removal by immobilized bacterial cells using annonaceous acetogenins for biofilm formation stimulation on polyurethane foam. J. Environ. Chem. Eng. 2017, 5, 189-195. [CrossRef]

9. Ohashi, A.; Harada, H. Adhesion strength of biofilm developed in an attached-growth reactor. Water Sci. Technol. 1994, 29, 281-288. [CrossRef]

10. Stanley, P.M. Factors affecting the irreversible attachment of Pseudomonas aeruginosa to stainless steel. Can. J. Microbiol. 1983, 29, 1493-1499. [CrossRef] [PubMed]

11. Sutherland, I.W. The biofilm matrix-An immobilized but dynamic microbial environment. Trends Microbiol. 2001, 9, 222-227. [CrossRef]

12. Niknezhad, S.V.; Asadollahi, M.A.; Zamani, A.; Biria, D. Production of xanthan gum by free and immobilized cells of xanthomonas campestris and xanthomonas pelargonii. Int. J. Biological Macromol. 2016, 82, 751-756. [CrossRef] [PubMed]

13. Nie, M.; Nie, H.; He, M.; Lin, Y.; Wang, L.; Jin, P.; Zhang, S. Immobilization of biofilms of pseudomonas aeruginosa ny3 and their application in the removal of hydrocarbons from highly concentrated oil-containing wastewater on the laboratory scale. J. Environ. Manag. 2016, 173, 34-40. [CrossRef] [PubMed]

14. Ferreira, L.; Rosales, E.; Sanromán, M.A.; Pazos, M. Preliminary testing and design of permeable bioreactive barrier for phenanthrene degradation by pseudomonas stutzeri CECT 930 immobilized in hydrogel matrices. J. Chem. Technol. Biotechnol. 2014, 90, 500-506. [CrossRef]

15. Swisher, R.; Carroll, G.C. Fluorescein diacetate hydrolysis as an estimator of microbial biomass on coniferous needle surfaces. Microb. Ecol. 1980, 6, 217-226. [CrossRef] [PubMed]

16. Fontvieille, D.A.; Outaguerouine, A.; Thevenot, D.R. Fluorescein diacetate hydrolysis as a measure of microbial activity in aquatic systems: Application to activated sludges. Environ. Technol. 1992, 13, 531-540. [CrossRef]

17. Jiang, S.; Huang, J.; Lu, H.; Liu, J.; Yan, C. Optimisation for assay of fluorescein diacetate hydrolytic activity as a sensitive tool to evaluate impacts of pollutants and nutrients on microbial activity in coastal sediments. Mar. Pollut. Bull. 2016, 110, 424-431. [CrossRef] [PubMed]

18. Liang, Y.; Zhang, X.; Dai, D.; Li, G. Porous biocarrier-enhanced biodegradation of crude oil contaminated soil. Int. Biodeterior. Biodegradation 2009, 63, 80-87. [CrossRef]

19. Picioreanu, C.; van Loosdrecht, M.C.M.; Heijnen, J.J. Two-dimensional model of biofilm detachment caused by internal stress from liquid flow. Biotechnol. Bioeng. 2001, 72, 205-218. [CrossRef]

20. Flemming, H.-C.; Wingender, J.; Szewzyk, U.; Steinberg, P.; Rice, S.A.; Kjelleberg, S. Biofilms: An emergent form of bacterial life. Nat. Rev. Microbiol. 2016, 14, 563-575. [CrossRef] [PubMed]

21. Hupert-Kocurek, K.; Guzik, U.; Wojcieszyńska, D. Characterization of catechol 2,3-dioxygenase from Planococcus sp. strain S5 induced by high phenol concentration. Acta Biochem. Pol. 2012, 59, 345-351.

22. Green, V.S.; Stott, D.E.; Diack, M. Assay for fluorescein diacetate hydrolytic activity: optimization for soil samples. Soil Biol. Biochem. 2006, 38, 693-701. [CrossRef]

23. Fisher, K.A.; Huddersman, K.D.; Taylor, M.J. Comparison of micro- and mesoporous inorganic materials in the uptake and release of the drug model fluorescein and its analogues. Chem. - Eur. J. 2003, 9, 5873-5878. [CrossRef] [PubMed]

24. Kasnavia, T.; Vu, D.; Sabatini, D.A. Fluorescent dye and media properties affecting sorption and tracer selection. Groundwater 1999, 37, 376-381. [CrossRef]

25. Sabatini, D.A.; Austin, T.A. Characteristics of rhodamine WT and fluorescein as adsorbing ground-water tracers. Groundwater 1991, 29, 341-349. [CrossRef] 
26. Marchlewicz, A.; Domaradzka, D.; Guzik, U.; Wojcieszyńska, D. Bacillus thuringiensis b1 (2015b) is a gram-positive bacteria able to degrade naproxen and ibuprofen. Water, Air, Soil Pollut. 2016, 227, 1-8. [CrossRef] [PubMed]

27. Manohar, S.; Kim, C.K.; Karegoudar, T.B. Enhanced degradation of naphthalene by immobilization of pseudomonas sp. strain NGK1 in polyurethane foam. Appl. Microbiol. Biotechnol. 2001, 55, 311-316. [CrossRef] [PubMed]

28. Jain, P.; Pradeep, T. Potential of silver nanoparticle-coated polyurethane foam as an antibacterial water filter. Biotechnol. Bioeng. 2005, 90, 59-63. [CrossRef] [PubMed]

29. Phoenix, V.R.; Holmes, W.M. Magnetic resonance imaging of structure, diffusivity, and copper immobilization in a phototrophic biofilm. Appl. Environ. Microbiol. 2008, 74, 4934-4943. [CrossRef] [PubMed]

30. Dikshit, P.K.; Moholkar, V.S. Kinetic analysis of dihydroxyacetone production from crude glycerol by immobilized cells of gluconobacter oxydans MTCC 904. Bioresour. Technol. 2016, 216, 948-957. [CrossRef] [PubMed]

31. Karunakaran, E.; Biggs, C.A. Mechanisms of bacillus cereus biofilm formation: An investigation of the physicochemical characteristics of cell surfaces and extracellular proteins. Appl. Microbiol. Biotechnol. 2010, 89, 1161-1175. [CrossRef] [PubMed]

32. Ingesson, H.; Zacchi, G.; Yang, B.; Esteghlalian, A.R.; Saddler, J.N. The effect of shaking regime on the rate and extent of enzymatic hydrolysis of cellulose. J. Biotechnol. 2001, 88, 177-182. [CrossRef]

33. Sirisha, E.; Rajasekar, N.; Narasu, M.L. Isolation and optimization of lipase producing bacteria from oil contaminated soils. Adv. Biol. Res. 2010, 4, 249-252.

34. Bisswanger, H. Enzyme assays. Perspect. Sci. 2014, 1, 41-55. [CrossRef]

35. Guilbault, G.G.; Kramer, D.N. Fluorometric determination of lipase, acylase, alpha-, and gammachymotrypsin and inhibitors of these enzymes. Anal. Chem. 1964, 36, 409-412. [CrossRef]

36. Frølund, B.; Griebe, T.; Nielsen, P.H. Enzymatic activity in the activated-sludge floc matrix. Appl. Microbiol. Biotechnol. 1995, 43, 755-761. [CrossRef] [PubMed]

37. Jørgensen, P.E.; Eriksen, T.; Jensen, B.K. Estimation of viable biomass in wastewater and activated sludge by determination of ATP, oxygen utilization rate and FDA hydrolysis. Water Res. 1992, 26, 1495-1501. [CrossRef]

38. Pietikäinen, J.; Pettersson, M.; Bååth, E. Comparison of temperature effects on soil respiration and bacterial and fungal growth rates. FEMS Microbiol. Ecol. 2005, 52, 49-58. [CrossRef] [PubMed]

39. Adam, G.; Duncan, H. Development of a sensitive and rapid method for the measurement of total microbial activity using fluorescein diacetate (FDA) in a range of soils. Soil Biol. Biochem. 2001, 33, 943-951. [CrossRef]

40. Sebastián, M.; Auguet, J.-C.; Restrepo-Ortiz, C.X.; Sala, M.M.; Marrasé, C.; Gasol, J.M. Deep ocean prokaryotic communities are remarkably malleable when facing long-term starvation. Environ. Microbiol. 2018, 20, 713-723. [CrossRef] [PubMed]

41. Cox, H.H.J.; Deshusses, M.A. Effect of starvation on the performance and re-acclimation of biotrickling filters for air pollution control. Environ. Sci. Technol. 2002, 36, 3069-3073. [CrossRef] [PubMed]

42. Roszak, D.B.; Colwell, R.R. Survival strategies of bacteria in the natural environment. Microbiol. Rev. 1987, 51, 365-379. [PubMed]

43. Ensign, J.C. Long-term starvation survival of rod and spherical cells of Arthrobacter crystallopoietes. J. Bacteriol. 1970, 103, 569-577. [PubMed]

44. Gengenbacher, M.; Rao, S.P.S.; Pethe, K.; Dick, T. Nutrient-starved, non-replicating mycobacterium tuberculosis requires respiration, ATP synthase and isocitrate lyase for maintenance of ATP homeostasis and viability. Microbiology 2009, 156, 81-87. [CrossRef] [PubMed]

45. Voelker, U.; Voelker, A.; Maul, B.; Hecker, M.; Dufour, A.; Haldenwang, W.G. Separate mechanisms activate sigma B of Bacillus subtilis in response to environmental and metabolic stresses. J. Bacteriol. 1995, 177, 3771-3780. [CrossRef] [PubMed]

46. Mielich-Süss, B.; Lopez, D. Molecular mechanisms involved in Bacillus subtilis biofilm formation. Environ. Microbiol. 2015, 17, 555-565. [CrossRef] [PubMed]

47. Sonenshein, A.L. Control of sporulation initiation in Bacillus subtilis. Curr. Opin. Microbiol. 2000, 3, 561-566. [CrossRef]

48. Majed, R.; Faille, C.; Kallassy, M.; Gohar, M. Bacillus cereus biofilms—same, only different. Front. Microbiol. 2016, 7, 1054. [CrossRef] [PubMed]

49. Correction: SinR controls enterotoxin expression in bacillus thuringiensis biofilms. PLoS ONE 2014, 9, e96707. 
50. Garcia-Ochoa, F.; Gomez, E.; Santos, V.E.; Merchuk, J.C. Oxygen uptake rate in microbial processes: An overview. Biochem. Eng. J. 2010, 49, 289-307. [CrossRef]

51. Norsker, N.H.; Nielsen, P.H.; Hvitved-Jacobsen, T. Influence of oxygen on biofilm growth and potential sulfate reduction in gravity sewer biofilm. Water Sci. Tech. 1995, 31, 159-167. [CrossRef]

52. Zhou, X.-H.; Qiu, Y.-Q.; Shi, H.-C.; Yu, T.; He, M.; Cai, Q. A new approach to quantify spatial distribution of biofilm kinetic parameters by in situ determination of oxygen uptake rate (our). Environ. Sci. Technol. 2009, 43, 757-763. [CrossRef] [PubMed]

53. De Beer, D.; Stoodley, P.; Roe, F.; Lewandowski, Z. Effects of biofilm structures on oxygen distribution and mass transport. Biotechnol. Bioeng. 1994, 43, 1131-1138. [CrossRef] [PubMed]

54. Zhang, L.; Wu, W.; Wang, J. Immobilization of activated sludge using improved polyvinyl alcohol (PVA) gel. J. Environ. Sci. 2007, 19, 1293-1297. [CrossRef]

55. Bandaiphet, C.; Prasertsan, P. Effect of aeration and agitation rates and scale-up on oxygen transfer coefficient, kla in exopolysaccharide production from enterobacter cloacae WD7. Carbohydr. Polym. 2006, 66, $216-228$. [CrossRef]

56. Ganesh, R.; Balaji, G.; Ramanujam, R.A. Biodegradation of tannery wastewater using sequencing batch reactor-respirometric assessment. Bioresour. Technol. 2006, 97, 1815-1821. [CrossRef] [PubMed]

57. Schäfer, S.; Schrader, J.; Sell, D. Oxygen uptake rate measurements to monitor the activity of terpene transforming fungi. Process Biochem. 2004, 39, 2221-2228. [CrossRef]

58. Greń, I.; Wojcieszyńska, D.; Guzik, U.; Perkosz, M.; Hupert-Kocurek, K. Enhanced biotransformation of mononitrophenols by stenotrophomonas maltophilia $\mathrm{kb} 2$ in the presence of aromatic compounds of plant origin. World J. Microbiol. Biotechnol. 2009, 26, 289-295. [CrossRef]

59. Battin, T.J. Assessment of fluorescein diacetate hydrolysis as a measure of total esterase activity in natural stream sediment biofilms. Sci. Total. Environ. 1997, 198, 51-60. [CrossRef]

60. Subramanian, S.B.; Yan, S.; Tyagi, R.D.; Surampalli, R.Y. Extracellular polymeric substances (EPS) producing bacterial strains of municipal wastewater sludge: Isolation, molecular identification, EPS characterization and performance for sludge settling and dewatering. Water Res. 2010, 44, 2253-2266. [CrossRef] [PubMed]

61. Amon, R.M.W.; Benner, R. Photochemical and microbial consumption of dissolved organic carbon and dissolved oxygen in the Amazon River system. Geochim. Cosmochim. Acta 1996, 60, 1783-1792. [CrossRef]

(C) 2018 by the authors. Licensee MDPI, Basel, Switzerland. This article is an open access article distributed under the terms and conditions of the Creative Commons Attribution (CC BY) license (http:/ / creativecommons.org/licenses/by/4.0/). 